\title{
Measuring Regional Differences in Employability in Hungary
}

\section{Levente Alpek ${ }^{1} \cdot$ Robert Tésits $^{1}$ (D)}

Received: 8 November 2018 / Accepted: 10 June 2019 /

Published online: 25 June 2019

(C) The Author(s) 2019

\begin{abstract}
The core of this study is to implement a statistical tool for measuring employability and identify its main functional factors using a theoretical model based on literary experience. The E-index explores the main elements of the Hungarian spatial structure and evaluates the territorial differentiation factors. The quantification of employability, beyond the complex indicator, is based on three more subdivisions: the quality of the economic and social environment and their relationship, the balance of supply and demand. The settlement types were identified by cluster analysis, the spatial "hot spots" and "cold spots" were localized using Getis-Ord's G* statistics. The analysis revealed that the spatial structure of employability, though similar in some respects to the pattern outlined by the unemployment rate, shows significant differences from several points. The difference can be clearly seen in both macro and microstructures. In a microstructural view, if the labor market situation is more favorable than employability, it is often resulted by the spatial proximity of a city with prominent economic indicators. Typically, the more accessible a job center, the more it is able to generate higher employment than what could be deduced from the level of employability. At the same time, high employability and potentially exploitable workforce is conceivable even in unfavorable labor market areas.
\end{abstract}

Keywords Employability · Labor market · Qualification · Economic activity · Hungary

\section{Introduction}

Due to the financial crisis of 2008 , the ratio of the unemployed individuals to the economically active population peaked in 2010 , which was followed by a deceleration.

Robert Tésits

tesits.robert@gmail.com

Levente Alpek

alpeklevente@gmail.com

1 Institute of Geography and Earth Sciences, University of Pécs, Ifjúság u. 6, Pécs H-7624, Hungary 
By the first quarter of 2018, unemployment rate fell to $3.9 \%$; however, more areas were affected by unemployment and other difficulties in the integration of available and accessible workforce. The expanding economy, along with new vacancies and the increasing need for work force necessitate the exploration of the options to more efficient employability, with special emphasis on the limiting factors and their relations. This is highly relevant in the case of individuals with low education skills and unfavourable mobility, who are extremely hard to employ owing to their circumstances and, in certain cases, the lack of motivation. Furthermore, as the majority of job vacancies are concentrated in the Central Hungarian region along with the western and northwestern parts of the country, the ratio of registered job seekers to the economically active, working age population significantly exceeds the national average (KSH [Hungarian Central Statistical Office] 2016).

The challenge of developing employability is a recurring theme in several Hungarian and international documents. The priority of the European Employment Strategy that is integrated into the Europe 2020 strategy has to be emphasised, as it seeks to improve both the quantity and the quality parameters of the employment market. There are several reasons why an inclusive development, which disperses the effects of economic development in the social structure, is required. The unfavourable demographic changes, low employment ratio especially among women and older job seekers, and the particularly high youth unemployment rate highlights the importance of the issue of employability in the European context as well (Europe 2020 Strategy 2010). The joint employment report of the European Committee also proves that the lack of worker skills as well as structural problems also considerably hinder economic growth (European Commission Brussels 2014).

Opportunities for improving employability are also closely related to the issue of regional competitiveness, as the spatial availability of an adequate amount and quality of workforce can make a significant contribution to social and economic development, thus reducing territorial disparities and enhancing regional competitiveness at both local and macro-regional levels (Vida and Dudás 2017; Kitson et al. 2004; Annoni and Kozovska 2010).

Employability is a complex issue, which, along with labour market integration, may include success in work performance and sufficient career building. The measures targeting the improvement of the efficacy of employability can be supported by the study of the regional and group specific questions of the issue, with special emphasis on the disadvantaged job seekers. However, in order to render employability suitable for index construction, it is essential to define a firm terminology and the relevant factors, to establish a concept drawing on the regional characteristics of the phenomenon and set up a model applicable in the Hungarian context.

The present study aims at carrying out the quantitative assessment of the phenomenon by applying a theoretical model based on former findings (Alpek and Tésits 2018). In addition, this research will explore the main components and factors of the Hungarian employability spatial structure by the application of the proposed employability index (E-index).

\section{Theoretical Background}

The quantification of employability relies on how researchers defined its components, factors and variables, and which characteristics they considered essential for the 
concept. The proportions used in former research is of great significance as employability is understood in the widest context, and the relevant literature, which discusses the concept in several scientific fields, relies on quintessentially different definitions, which result in diverse factors. Some of the research expresses the undefined nature of employability and its openness to interpretation (Harvey 2001), which draws attention to the need of target-specific study. Research emphasises the importance of defining the conceptual frame that serves as a background of the assessment. This question is pivotal in the context of spatiality, as the problematics of employability may appear differentially in space and time in the case of each group (McQuaid and Lindsay 2005), while they are not only dependent on individual factors but structural and economic processes as well (Peck and Theodore 2000).

The majority of the research approaches employability from the job seekers' characteristics identified as soft factors. Indicators include knowledge acquired during training, versatile skills and health condition; in addition, personal, social and a wide range of other competences valued by the labour market, such as strategic thinking, are also accounted for (York 2006; McQuaid and Lindsay 2005; Blades et al. 2012). According to Yorke and Knight (2006), employability is primarily dependent on efficacy beliefs, self-theories, subject understanding, skills, qualities and the quality of strategic thinking (USEM model). The CareerEDGE model developed by Dacre Pool and Sewell (2007) states that the employability of the individuals relies on their work and life experience, degree subject knowledge, key competences, which are the bases of flexibility, and emotional intelligence as well. Fugate et al. (2004) propose a model that relates employability to three factors: personal adaptability, career identity including personal experiences and goals, and the interrelationship of social and human capital. The Bologna Follow-up Group treats the issue of defining employability by factors applicable to individuals (Bologna Process. Stocktaking Report 2009), thus the concept depends on such competences that enable the individual to find work or become selfemployed besides successfully maintaining employment, keeping the job or being mobile on the labour market. If it is assumed that higher education skills enhance, though not exclusively, the individual adaptability to the employment market, these definitions, among other factors, draw attention to the importance of the skills indicator in the measurement of the phenomenon. The skills indicator, beyond the acquired qualifications, indirectly renders individual adaptability suitable for indexing on the settlement level in accordance with the goals of the present study; moreover, it incorporates such variables into the model that can be connected to the health status and labour market integration capacities (e.g. the ratio of the long-term unemployed, relative indicator).

Nevertheless, the above definitions and models restrict the spatial measurement and the study of employability to certain factors, as they principally concentrate on the qualities and the abilities of the individual. The concept has to be approached from a wider angle that stresses the significance of the environmental factors. In addition, a broader scope is important because higher qualifications reduce the risk of unemployment and protect from losing the job, however, the availability of qualified work force alone does not secure high levels of regional employability. Thus the nature of the employment market environment is a significant factor of the employability among other markers describing the qualifications and skills setting of the available work force (Thijssen 2000; Thijssen et al. 2008; Forrier and Sels 2003; McQuaid and Lindsay 2005), including the labour market both within and without the company (Forrier and 
Sels 2003). In the widest context, the concept can be defined as the probability of employment in the labour market or the ability to acquire and maintain the job (Hillage and Pollard 1998; Harvey 2001). Nemeskéri (2014) principally defines employability as the correspondence between the expectations of the employers and the abilities of the job seekers (applicants). In accordance, those individuals are highly employable who can fulfil the expectations of the employers in the given time and, remarkably, space. A number of researchers emphasise the role of the circumstances and the environment; they draw attention to the fact that employability is significantly context-based, and it is influenced by many outside factors beside the correlation of demand and supply. The closer (marital status, household circumstances, health and environment, demographic relations) and wider (settlement environment, mobility) socioeconomic relations of the individual are included in these outside factors (Thijssen 2000; McQuaid and Lindsay 2005; McQuaid 2006). The effect of the outside and contextual factors on employability is of importance in the employability process model proposed by Forrier and Sels (2003), who underline the significance of available jobs. When discussing employability, McQuaid and Lindsay (2005) also emphasise the importance of the different layers of the elements in the socioeconomic environment. Their model is in one part based on personal circumstances (household circumstances including caring responsibilities, safe housing; access to resources, such as financial and social capital), while the other part relies on external factors (such as labour market environment, sector-specific demand distribution, structural factors; macroeconomic stability, vacancy characteristics, recruitment factors, e.g. discrimination). Hillage and Pollard (1998) also highlight the substantiality of the environmental factors. Their definition treats employability in the context mentioned above (ability to fill the vacancy, mobility on the labour market, promoting individual characteristics), but the quality of the labour market environment is a predominant constituent of employability.

These wider approaches provide the foundation of measuring employability and define the components (employer-side, labour market factors, demand-side approaches; jobseeker/employee-side, supply-side approach; the relationship between the two, mixed approach). From this aspect, the share of the active age population can be another important factor when measuring the supply side of labour market and employability to which, in terms of regional competitiveness, Huovari et al. (2002) call attention. These aspects incorporate an extensive amount of possible indicators; in addition, they are determined by the relevant social group in which employability is studied. The components of employability are summarised by Kun (2008) and the following factors are identified: the sufficient fulfilment of basic needs, housing, clothing, the possession of documents necessary for the vacancy, solving the problem of household care of the family members, travel to the workplace, health status, knowledge, abilities and skills, legal knowledge and other psychological factors. Thijssen (2000) pursues the question, and the widest scope of his threefold interpretation of employability allows for all those related factors that influence the labour market position of the individual.

Consequently, those active or passive means constitute a significant aspect of employability that extend the range of vacancies accessible to the individual (including public work opportunities). However, the opportunities are considerably improved if the economic environment is able to absorb the local labour force (Tésits et al. 2018), which also underlines the significance of this factor. Furthermore, most of the vacancies 
were concentrated in the Central Hungarian or the Western and Middle Transdanubian region in 2018 (KSH). This fact thus necessitates the incorporation of spatial mobility indicators into an employability model that measures regional characteristics. The approaches mentioned above make it clear that employability can be assessed by several indicators, all of which have to be taken into account if the aim is to establish a complex indicator that describes the phenomenon.

Compared to the earlier literature, the present research is innovative in its objective to establish such a model, or indicator, that enable the regional and group specific measurement of employability. The earlier models, although they contributed to the understanding of employability, primarily concentrated on those characteristics and abilities of the individual that limited the indexing of these qualities in terms of spatial structure components. Therefore, the formation of such a new indicator was needed, which can describe employability in a broader context and facilitate determining the distance between the population of the examined region and the primary labour market while concentrating on the job seeker group. In this manner, the indicator can also contribute to the reintegration of the job seekers and the success of the supporting, specific employment policy programmes.

\section{Objectives}

The present study specifically aims at developing such an indicator (employability indicator, E-index) which enables assessing the regional differences in employability, discovering its spatial structure and exploring its main relations. The target area is the entire region of Hungary, and its aspect is the category of settlements. The objective above is accomplished through the following subgoals.

The assessment of employability is based on the theoretical framework proposed earlier by the authors (Alpek and Tésits 2018), which identifies the main factors. The theoretical frame below will introduce the aspects that are related to the objectives in connection with employability in the present study. The present research aims at providing these groups of indicators with variables, filtering the initial indicator table and quantifying the employability index.

The study also intends to survey the employability status of individual villages and cities by the application of the employability indicator (E-index) established for the purpose to measure employability. This framework will explore the macro and micro level differences in the Hungarian spatial structure, their connection to the labour market, the key features and the hot spots, which are definitive in the regional equalisation of the employability relations (Fig. 1). Measuring the phenomenon enables the identification and assessment of certain regional differentiating factors, thus the research aims at finding what factors contribute to the spatial structure differences in employability and how they exert influence.

\section{Research Methods}

Literature reveals that employability is such a multi-faceted, complex term that is approached in several ways, so those secondary sources are favoured that define the 


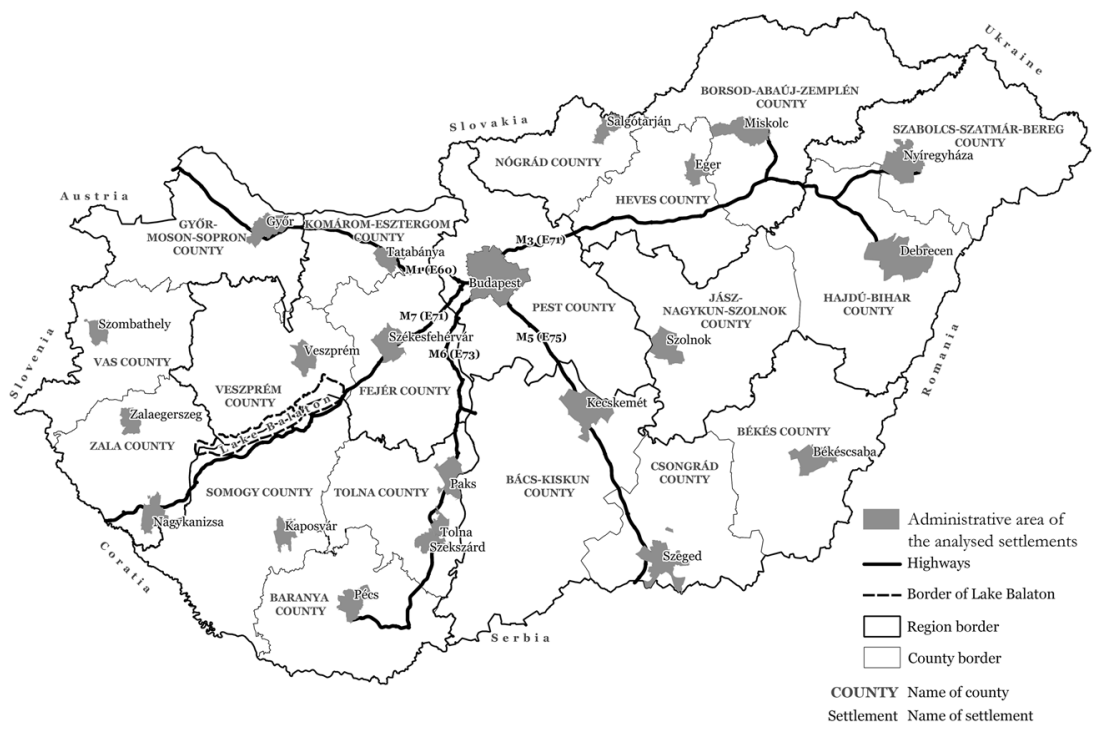

Fig. 1 The most important topographic elements in the study

theoretical frame of employability, its factors and assessment methods through national and international investigations and models. The present analysis predominantly approaches the concept of employability from the issue of regional employability, which is understood as the labour market possibilities of the population, or a group of that population, in a spatial segment, whose main three components are the economic context (and thus labour demand), labour supply/social relations and the quality of the connection between the two (Fig. 2). Employability proper means the labour market integration abilities of the individual, while its broader sense is understood as the ability of the individuals to form a long-term and sufficient career. If the value of regional employability is high, the employment relations of the settlement and/or the quality of the human resources are advantageous. In the case of a specified regional unit, the indexation of employability based on the present model is determined by measuring the two components and their interconnection with specific indicators (Alpek and Tésits 2017).

In the assessment of employability, the present research uses the framework of the above model and relies on data provided by the National Spatial Development and Planning Information System, the Ministry of National Development, the Hungarian Central Statistical Office, the National Tax and Customs Administration of Hungary (NAV) and GeoX Ltd.

The quantification of employability in regional units was carried out with the application of the employability complex indicator (E-index) taking the advices of literature (Pénzes 2014; Lukovics 2008) into account in the following steps. Earlier published findings were taken into consideration and those indicators related to the assessment model were identified, which theoretically support the quantification of the level of employability. The resulting indicator table contained 509 potential variables. Pre-filtering was conducted based on three principles to decrease the amount of variables:

- accessibility (the specific variable exists and is freely obtainable) 


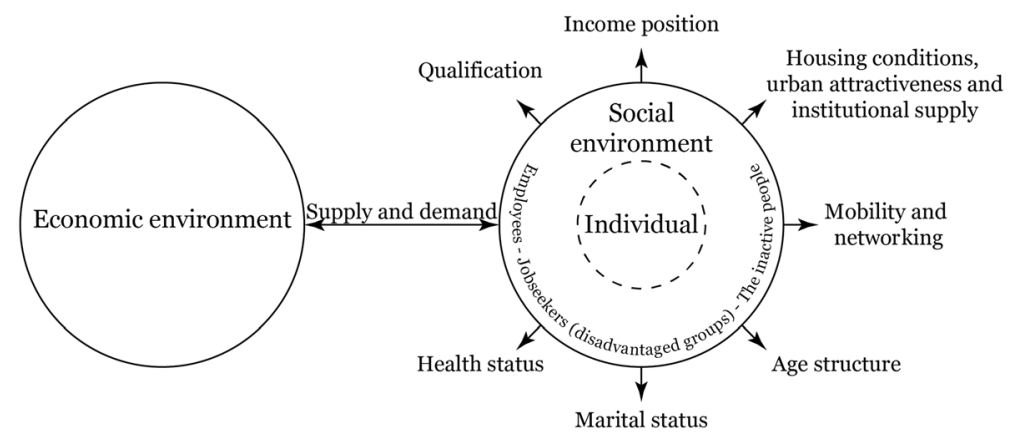

Fig. 2 Model of measuring employability on a regional basis. Source: Authors (2017)

- $\quad$ settlement-level availability

- number of missing values.

The initial data table included only those variables that were available in at least $85 \%$ of the settlements; in practice, the indicator that contained the highest number of missing values was available in $86.1 \%$ of the settlements. The remaining amount of variables was aggregated in part. In addition, the earlier established multiplication index, which measures the general scale of cumulated disadvantages, was also integrated (Alpek and Tésits 2018):

$$
\begin{aligned}
& \text { Multiplication index (M) } \\
& =\frac{\text { the total number of individuals with specific disadvantages }}{\text { the number of registered job seekers }} .
\end{aligned}
$$

The numerator of the multiplication index gives the amount of individuals with the examined disadvantages per category, the denominator contains the total number of the registered job seekers; so the multiplication index defines, presupposing the even distribution of disadvantages, how many disadvantages would be found per each registered job seeker. If the indicator rises, the tension generated by the multiplication of the disadvantages in the given spatial entity also increases. The indicator comprises of 5 disadvantages:

- number of individuals seeking employment for more than 180 days

- number of registered job seekers with disabilities

- number of registered job seekers over 50

- number of registered job seekers with elementary school qualification or less

- number of registered entry-level job seekers.

The maximum value of the multiplication index is 5 , which can be measured in the extreme case when, in the given region, each of the registered job seekers have all of the disadvantages. The other extreme value is zero. In this case, the given spatial entity does not have any registered job seekers who possess any of the above disadvantages.

The institutional density of the settlements is conducted by the institutional density index as follows 


$$
\text { Institutional density index }(\mathrm{I})=\frac{\sum_{i=1}^{n} x_{i}}{n} \text {, }
$$

where

$\mathrm{x}_{\mathrm{i}}$ is 1 if the institution is available in the given settlement; 0 if it is unavailable, and

$\mathrm{n}$ represents the number of examined institutions.

The indicator comprises the following institutions that are substantial for the employability of the job seekers:

- employment agency

- registrar's office

- bank outlet

- post office (permanent postal service outlet, postal outlet, postal agency, subsidiary post office)

- elementary school

- nursery

- daycare facility

- kindergarten

- general practitioner service for children

- family support services.

From the variable pairs calculable from each other, only those were included in the table that, based on literature, measure employability in the more significant aspect.

The next step included transforming all the variables into ratios; forming the proper base was followed by a preliminary categorisation, which resulted that all the indicators were connected to a category created by the conceptualisation of employability. Prefiltering and merging reduced the initial variable number from 502 to 99 . The values measured along the various dimensions were standardized by projection to a minimum-maximum interval. In the next step, the values thus established between 0 and 1 had to be "given direction". As a result, higher and lower indicators represent more and less favourable employability levels, respectively, in the case of all the values.

The filtering of the standardised and directed set of variables was conducted through principal component analysis. The method of principal component analysis was selected on purpose, as the primary goal of this phase of the examination, in order to support the better interpretation of the categories, was to decrease the number of variables while losing a minimal amount of information (Sajtos and Mitev 2007). Accordingly, it was a prerequisite in the case of every indicator group that they should comply with factor analysis (Bartletttest significance level<0.05) and the final variable set should reach the possible highest KMO value per indicator group (the smallest KMO value was 0.553 , the highest KMO value was 0.865 , every indicator group complied with the basic requirements). The choice of varimax rotation is justified by the fact that this phase targeted the strongest possible connection of the individual indicator groups and the respective variables; in addition, maximizing the variance interpreted by the factors was also a prerequisite. The principle component analysis only kept those variables that had a communality value of 0.25 or above, their factor weight exceeded 0.5 - the factor weight was less 
than 0.5 in the case of only one variable and the smallest weight was 0.493 and they could be attributed to a factor. In order to extend the application of the value of the index to the widest range of Hungarian settlements, those variables were favoured that were available in the broader range of settlements, thus it was made possible to provide $97.1 \%$ of the Hungarian cities and villages with an E-index. Finally, the very highly correlated variables (above 0.9 ) and those with very low variance (thus differentiating less) were filtered out. Accordingly, for the basis of the index, such an indicator table was formed that unambiguously assigned the individual variables to indicator classes and eventually contained 49 components.

To define the employability indicator (E-index), first the category averages (indicator group averages) were calculated, whose values were further averaged. Apart from the complex indicator, the analysis and indexation of employability were carried out in three subdimensions:

- eE-index: quantifies the economy-related component of employability, corresponds to the indicator class "Economic activity, employment (G)"

- sE-index: quantifies the society-related component of employability, its constituents are the indicator classes "C", "E", "Kp", "J", "I", "M" and "K", whose average gives its value

- $\mathrm{KK}$ : the indicator class that quantifies the correlation of demand and supply

By applying the means above, the analysis, besides examining the spatial structure of employability, also specifically explores its social and economic environment and their connection.

In the analysis of the spatial structure, the identification of the dynamic "hot spots" and the disadvantaged cold spots of employability are carried out with local $G_{i}^{*}$ statistic (Getis and Ord 1992). The use of this method is not without precedent in the Hungarian territorial studies (Vida 2016; Szakálné Kanó 2011).

$$
G_{i}^{*}=\frac{\sum_{j=1}^{M} w_{i j} d_{\mathrm{j}}}{\sqrt{\frac{\sum_{j=1}^{M} d_{j}^{2}}{M}} * \sqrt{\frac{M \sum_{j=1}^{M} w_{i j}^{2}-\left(\sum_{j=1}^{M} w_{i j}\right)^{2}}{M-1}}},
$$

where

$\mathrm{M}$ is the number of analysed spatial units,

$\mathrm{w}_{\mathrm{ij}}$ is the $\mathrm{j}^{\text {th }}$ component of the $\mathrm{i}^{\text {th }}$ line in the neighbourhood matrix,

$\mathrm{dj}$ is the distance between the attribute value of the characteristics.

In the course of the study, we took the limitations of the applicability of the method into consideration, which appear in several articles (Szakálné Kanó 2011; Dusek and Kotosz 2016). Accordingly, the analysis has taken into account the distorting effect (on the neighbors and thus on the results) of the borders and small village areas. In addition, the choice of the settlement level was justified by the fact that we can evaluate the spatial structure of employability while minimizing the distorting effect of the size of the areas. 


\section{Results}

\section{Spatial Differences in Employability}

Examining the relationship between the E-index built up from the above indicator classes and the unemployment rate, it became clear that in some of its components, the spatial image of employability reflects the pattern drawn by the unemployment rate; in many instances. However, there are significant differences in the territorial image of the two variables, which exemplify that employability and the labour market environment are, naturally, interrelated phenomena, still they do not cover the same area. Regions with adverse labour market situation can also conversely have high employability numbers (Fig. 3).

In the relation of the unemployment rate and the E-index, a considerable discrepance can be observed along the western border of the country. In this region, the employment of the local inhabitants is significantly better than the E-index (i.e. employability) would suggest, primarily because the labour and the economic environments are more favourable. The shortage of labour supply plays an important role in this phenomenon, which may require employers to be more flexible in certain cases when hiring labour force. However, the high ratio of industrial vacancies increases the number of job positions available to individuals with low education skills, which is complemented by the labour demand of the employers - of not only the secondary sector - in the neighbouring countries. The contrast is Northern Hungary and the Northern Great Plain, particularly the Miskolc-Nyíregyháza-Debrencen triangle, where, based on employability, a much lower unemployment rate would be expected. The same applies to the Balaton-Székesfehérvár and Kaposvár-Pécs line, which will be accounted for when the factors are examined.

Examining the issue in a broader context and if the entire country is considered, it is a general phenomenon that the sub-periphery is dominantly in a much more favourable

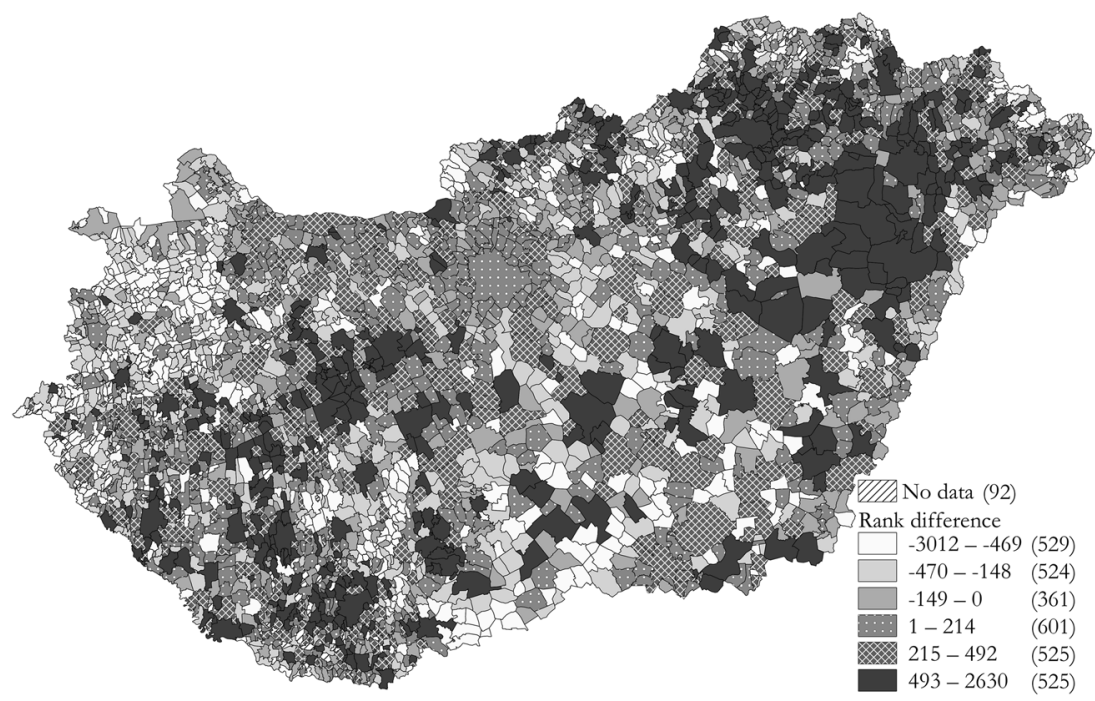

Fig. 3 Differences in the spatial structure image outlined by the relative indicator and the E-index (2011) 
employment position than in terms of actual employment; however, in certain settlements, especially in the less populated villages, the employment status is far more advantageous than expected. In a labour market situation where the employability characteristics are surpassed, very frequently a nearby centre with more favourable employment and service sector attributes (e.g. Szeged, Kaposvár, Dombóvár, Paks) plays the crucial part. Predominantly, the more powerful and easier accessible a local employment centre is, the more it can generate more substantial employment than the employment level of its environment (e.g. Galvács). This effect can be clearly seen in such districts, which are to be developed by complex programmes (the role and status of the centres will be explained in detail below). It is also very frequent that a settlement in an advantageous position will benefit more from the creative solutions (e.g. Belecska) aimed at developing the local economy and/or employment, and the effective application of public employment means. In the case of settlements with typically few economically active inhabitants, the presence of local services and a small number of smallholder farmers generate a better labour market environment (e.g. Égerszög). In the dimension of the E-index, the macrostructural differences can be observed between the economically more advantageous regions and the remaining areas of the country, while the microstructural faultlines primarily appear between cities including their vicinity and villages (Fig. 4).

In addition, the employability spatial structure is also continuous in the sense that regions in a more favourable position (Budapest and its agglomeration, the Balaton region, the northwestern border region) gradually shift - through a zone with gradually decreasing values - into districts with lower employability index values. This district in the intermediary zone is tinged by such settlement groups with an outstanding employability index (hot spots, employability centres), which may play a significant part in the spatial spreading of those effects (e.g. economic boom) that favourably influence the employability of the population (Fig. 5). Their importance is heightened by the fact that these local employability hot spots can dynamise their region, therefore they can also increase the resistance of their area. This latter effect is reflected by the micro structural

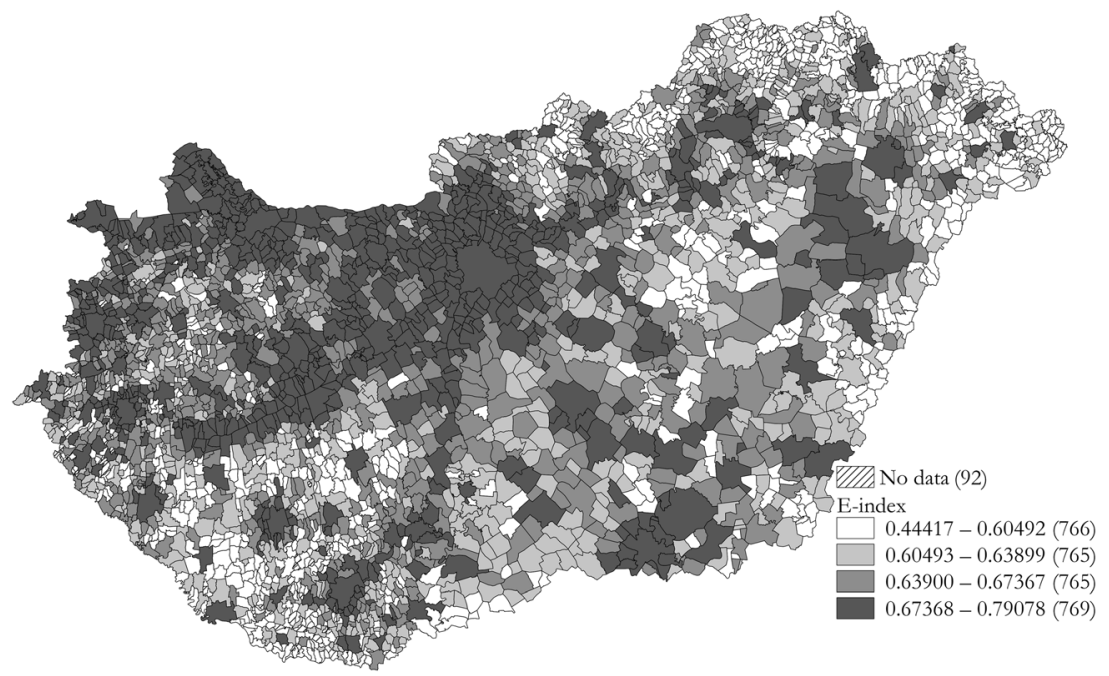

Fig. 4 E-index values (2011) 


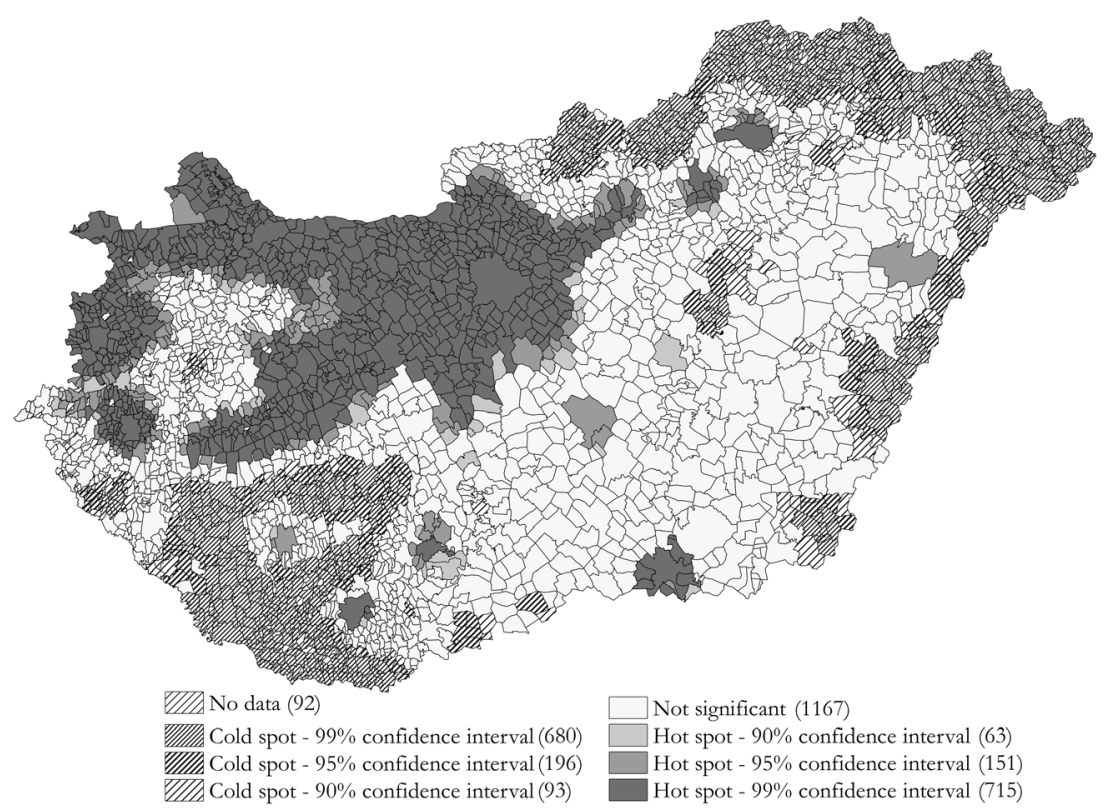

Fig. 5 Employability hot spots in Hungary

image, which reveals that the indicators are significantly better around the scattered centres, which are predominantly represented by bigger cities and their vicinity, and the values are much more below the national average farther away from these centres. The augmenting effect of the hot spots on employability depends on three factors: the level of spatial mobility and networks (integration into networks), the combined level of employability (E-index average) and the population size. The high degree of network integration fosters a more intensive incorporation and utilisation of the "local" resources (e.g. commuting to the centre for employment does not consume so much money or time) including the circulation of information (e.g. on vacancies or the requirements of the employers) and various social and economic effects. As a distinct analysis will reveal below, the E-index complexly quantifies the employability status of the given hot spot population, while the primary significance of the population size is that the hot spots with their higher indicators may have a more extensive labour supply because of their volume, and they may consequently have a more substantial local customer base. The latter two aspects are modified by several other factors: the former is heavily influenced by the economic activity of the population, the second by income relations, which draws attention to the necessity of taking into account the three components - integration, E-index and population size - in the assessment of employability centres.

The location of the hot spots is subject to change, it is determined by how the role of the centre and its periphery (belt) are interpreted and whether only those settlements are included, which are significantly attached to the hot spot, or the ones farther away from the centre are also taken into account. The present study examines the hot spots in relation to the centre and those settlements that are significantly attached to the hot spot; the centre is the settlement with the largest population of the hot spot and the periphery consists of the nearby settlements. In the absolute approach, the centre and its 
environment, which is comprised of settlements with a considerably smaller population than that of the centre, has a weight that equals to the weight of the centre. This approach, although it overweighs settlements with less inhabitants, is justified by the increased sensitivity to the environmental conditions of employability (e.g. if the vacancies are small in number or they are more diverse, even individuals with more qualifications will have difficulty finding jobs). Since the employability relations of the periphery predominantly fall behind the attributes of the centre, in this dimension the best E-index values can be observed in the case of hot spots with the smallest belt (Debrecen, Szolnok, Pécs and Kecskemét). The absolute value of the differences between periphery and centre are the highest in Szeged, Eger and Miskolc. The Szekszárd hot spot shows irregularities, as it has the second largest periphery, but the E-index mitigating effect of the periphery is considerably smaller. This is due to the better employability relations of the periphery instead of the weaker values of Szekszárd. The Szekszárd hot spot attribute of having the smallest central population is balanced by less "resistance" that employability possibilities have to counter in spatial extension owing to the more favourable values of the neighbouring settlements.

In the relative approach, the evaluation of the hot spot is based on the weighting of the examined indicators (spatial mobility and networks, and E-index) of the relevant settlements with their population. In the resulting order, the gap between the hot spots widens and the relative weight of the Debrecen hot spot decreases, while the values of Szeged, Pécs and Miskolc considerably improve. As these centres are more populated than their belts, these characteristics are more dominantly present. In the case of Szolnok, the lack of highway access and, compared to the other hot spots, the relatively small population size was responsible for the decline (as a rule, the most powerful hot spots have highway connection). The relative status of Kecskemét, compared to its absolute position, shows a smaller decline, which is due to its better network level. Eger is on a moderate growing track with special hot spot characteristics, as its attached belt is the least integrated, but it has a 14-settlement belt, which is the highest number among the hot spots. The special feature of the Szekszárd hot spot is that while in the case of the rest of the hot spots the largest and the second largest settlement have a very low population ratio (the population of the second largest settlement is only 1.9-5\% of the centre), this value exceeds $32 \%$ in the case of Szekszárd, as there are two settlements in this district (Szekszárd and Tolna) with an outstanding population weight. Although they boast with more favourable values, these hot spots - in comparison with the larger settlements of more than 100,000 inhabitants - have more moderate indicators both in the dimension of the E-index and the even more diversely extreme values of integration. It is the Kaposvár hot spot, whose relative position decreases to the greatest degree in the weighted model. The interaction of three components can be observed among the factors. The employability level of the hot spot is weakened by the lack of direct access to a highway; in addition, the Kaposvár hot spot has the smallest population, while its employability relations (E-index) are only moderately improving; the two "belt settlements" did not have a much worse value than Kaposvár, but the most populated settlement itself had the smallest E-index compared to the rest of the hot spots.

On the whole, it can be concluded that the districts of the central settlements are less integrated into the national networks than the centre, furthermore, their spatial mobility and network relations are weaker than the level of E-index taken in a wider sense. 
However, the relative status of the centres is very similar, the relative deviation of their E-indices is $3.6 \%$, thus, although their bottleneck values may differ, their employability relations are uniformly outstanding regarding the possibilities; the smallest E-index value of the Kaposvár centre is surpassed by approximately $5 \%$ of the settlements, while the largest value of Szeged is only exceeded by $1 \%$ of the settlements.

\section{Role of the Specific Factors (Indicator Groups) in the Spatial Structure of Employability}

Three effects influence the formation of the regional differences: the quality of the economic environment, the attributes of the social environment and the demand-supply correlation that signifies the relation of the two. Considering the strength of the effects, the social factors are more definitive in the creation of spatial differences; it is followed by the economic environment and the tensions in the matching of demand and supply. This also explains why employability is distinct from the actual labour market, as the latter is primarily defined by the quality of the economic environment. The discrepancies of employment and employability are obvious, as whatever employable the individual may be, if there is no vacancy nearby or within mobility reach, employment will fail. Self-employment might constitute a partial solution, but its viability can be seriously influenced by the predominantly unfavourable local demand in the regions with low E-index values and the quality of the social environment (e.g. income status).

A more detailed picture is drawn by considering the factors (indicator groups) that form the components of the three categories of social and economic environment and their correlation. Although the most substantial spatial differentiating factor is a social one, qualification, the next in rank is an economic factor (economic activity, employment), followed by another social aspect (spatial mobility and networks) and, finally, demand-supply.

The most powerful spatial differentiating factor is qualification, which is already a familiar and substantial factor in labour market status and the spatial differences of unemployment as well. Qualification also has an important role in employability, as it interacts with several other attributes and fundamentally influences the labour market performance of the individual. This is verified by the fact that qualification is the very indicator group that reveals close correlation with the highest number of other factors. Settlements with unfavourable qualification relations are also ranked low among the settlements in the dimension of other socioeconomic factors. The strongest comovement can be observed with the income status (corr. 0.835), which is, not exclusively, followed by economic environment (corr.0.779), housing conditions and institutional density (corr. 0.741). Thus, in areas where qualification is unfavourable, such settlements will be found in which income status will further hinder job seekers in the self-sufficient increase of employability, the attainment of an appropriate mobility level and/or relocation; however, the latter might increase the spatial differences considering employability. The impediments of the former decrease the ability of the labour force to work at home and regenerate. This is partly due to the settlement size, which is justified by the fact that more than $87 \%$ of the villages with less than 500 inhabitants could be found among the settlements with an index value in the lowest quartile of the qualification indicator group. Troubled access to the institutions may reduce income status, as they may generate mobility dependence and thus decrease flexibility. 
In addition, qualification also ranks first in the village/city relation, furthermore, its spatial differentiating effect is greater in the case of the cities i.e. raising the employability level and reducing the regional differences may primarily depend on the development of the local human resources and the attraction and preservation of skilled labour. However, the housing conditions, which will be analysed in detail below, settlement attractiveness and institutional density are also key factors in this process.

Accordingly, the effect of qualification on the employability spatial structure amplifies the spatial differences mentioned above (the deviation of the qualification indicator is almost two and a half times larger than that of the E-index), the contrasts become more intense, the intermediary zone gets more fragmented, the national image turns to be mosaic. Nevertheless, there is a potential in making active the local inhabitants of the settlements with more unfavourable qualification attributes, as this is less hindered by the age diversity of the local inhabitants (corr. -0.91), which means that improving the local income, housing and quality relations may render a wider range of younger labour base available.

The category ranking second among the differentiating factors that define spatial employability is economic environment, whose spatial structure image considerably differs from the pattern drawn by qualification relations. This dimension is predominantly characterised by the size of the disadvantaged border region, which has an unfavourable employability index, thus the problem is rendered a homogeneous one in the village/city relation as well. A broad zone is forming that lags behind in economic activity and labour market contribution, which, apart from sporadically present local hubs, includes certain areas of Northern Hungary, the Northern and the Southern Great Plain. In these regions, the competitiveness of even those areas is decreasing, which otherwise have a favourable employability position in the dimension of qualification. This effect, although in a weaker form, can be observed in the cities of Southern Transdanubia. The centre of mass of the economic environment involves the settlements located on or to the north-west of the Nagykanizsa-Balaton-Budapest line.

In the regions where the values of economic environment are higher, unemployment affects less people, the population has better income status and qualification level, which significantly influence employability. These areas also reach a higher employability value in the relation of marital status, which is partly due to the presence of a more sufficient ratio of social institutions (e.g. nursery vacancies) as well as better income and employment opportunities in these villages and cities.

Because of its strong correlation with the unemployment spatial structure image (corr. -0.873), the economic environment offers the most suitable way-among all the variable groups - of tracing the demand, or employer, side of employability. The favourable value of this indicator class is a reliable precursor of the competitiveness of a settlement, as it shows a positive co-movement with the strongest regional differentiating factor (qualification) and the other significant categories of indicators (of all the variable groups, the highest correlation value, 0.695) that describe the relation of demand and supply.

The role of spatial mobility and networks has to be highlighted among the spatial differentiating factors, not only because this factor has the third largest "space-forming" force, but also because its spatial structure image, due to a set of special characteristics, markedly differs from any of the other variables. Furthermore, it has a heightened importance; if the aim is fostering the dispersion of the economic effects and reducing 
the spatial structure discrepancies, this is the factor, provided employability is backed up by favourable social conditions, which can channel the favourable effects as a component of the same social conditions. In other words, from two "hot spots" with identical employability conditions, the one with a better integration into networks is more probable to gain from the favourable effects.

The first striking difference compared to the earlier mentioned indicator groups is that the factor of mobility and integration into networks has continuous and favourable status areas even in the eastern part of the country; the indicator is exceptionally high in the Debrecen-Nyíregyháza-Miskolc triangle, and, due to its nature, along the highways. It can be attributed to the effect of highway M6 that the zone with Budapest in the centre is an area with higher accessibility spreading as far as Pécs. However, as a contrast, even regions with more advantages have extensive, less integrated spatial parts, especially at the shared inner border of Györ-Moson-Sopron, Zala and Vas counties. There are at least two reasons for this phenomenon. First, mobility is predominantly influenced by linear infrastructure, primarily the route of highways, and the location and relative spatial position of economic and employment centres. Second, the internet, which enables efficient connection to digital networks, and especially broadband internet can be accessed in the larger cities, where a critical amount of consumers concentrates, or along the line linking these cities. It is not a mere coincidence that this indicator group is loosely connected to the other factors of employability. It can be stated that integrated regions with a high degree of mobility are urban, economically developed areas, regional or local centres, which have a positive connection to more favourable qualification environments, better housing conditions and established institutional background. Furthermore, this indicator has the third largest deviation in social factors following qualification and economic environment, while the second largest is relative deviation, thus the contrasts are clearly defined, as more remote areas are considerably more isolated than the well or moderately integrated zones.

Beside the three factors that influence the spatial differences of employability, the indicator index ranked fourth, which serves the purpose of measuring the correlation of demand and supply, the two differing sides, and their equilibrium, which is a separate category in itself. This component shows a remarkably unique spatial structure image of the three larger hubs (Budapest, Balaton and Györ-Moson-Sopron county) and the numerous smaller centres. The spatial structure is mosaic in nearly two-thirds of the country, its relation to the economic environment is the most extensive (an important component as logic dictates as well), and shows a moderately strong, positive relation to the income and qualification background. However, due to several effects, they are not in exact alignment.

First, the quantity parameters - the number of vacancies - also rely on their heterogeneity, which renders employment accessible for a wider range of social groups and thus increases employability. In settlements with a more favourable economic status, more intensive and heterogeneous employment makes finding vacancies easier for job seekers, therefore they are less likely to suffer from long-term unemployment.

Second, public employment has a significant effect on employability, especially in the disadvantaged areas. One of its most important aspect is that the programmes may offer a chance for those disadvantaged individuals who are unable to find jobs in the primary labour market because of the low capacity of local employment or other 
reasons (e.g. qualification). Considering the composition of public workers (CseresGergely 2014), the effect is exceptionally strong among individuals with low education skills. As far as the local governments can include a wide range of job seekers into the programme within a year's time, the ratio of long-term unemployed can significantly decrease. In addition, an income larger than the support substituting for wages, major reduction of the mobility costs due to the local position and a higher level of labour socialisation may appear as the effect of public employment programmes on employability.

\section{Conclusion}

The present study aimed at developing such an indicator (E-index), which enables the indexing of the employability relations of the Hungarian population and facilitates the identification of the various regional differences and the responsible key factors that contribute to these discrepancies.

The territorial level of the survey was given by the settlements of Hungary, but the employability model on which the measurement is based, and the applied methodological approach allows the application of the results to several countries or smaller regional units. The main challenge in this respect is the full availability of data, the chosen level of territorial aggregation, the method of data aggregation, and the comparability of the variables in each indicator group in the case of a comparative study. Accordingly, if the study is extended to a wider range of countries, when compiling the indicator table, it is important to ensure the proper representation of the specific subdimension of employability also enabling international comparison.

The analysis has revealed that the spatial structure image of employability, although it reflects the pattern of the unemployment rate in some of its aspects, shows considerable variance in many instances. This is highly apparent along the western border and in the districts to be developed by complex programmes. The border areas have a dominantly more favourable position concerning the actual employment than it would follow from their employability relations, while the latter ones take a less favourable position. This phenomenon underlines that although employability and labour market position are closely interrelated, they do not cover the same problematics. Even disadvantaged labour market position areas might have high employability and a potentially available work force.

It is often a close city with favourable economic indicators that is responsible for a better employability and labour market position of a settlement than it would otherwise follow from its employability conditions. Typically, the larger a local employment centre is, the more it is capable of generating an employment level "higher" than the employability level. In addition, it can also be observed that the creative solutions aiming at the development of local economy and/or public employment are significant factors if they are properly carried out in a given settlement.

Taking employment of the population and the extension of other factors influencing diverse forms of employability (e.g. economic growth) into consideration, these central areas designate a crucial role to certain employability "hot spots", whose weight was quantified by three factors: spatial mobility and networks (integration into networks), the complex level of employability (E-index average) and population. Analysing the 
"hot spots" in general, it can be concluded that the district of the central settlements is less integrated into networks than the centre, its spatial mobility and network relations are weaker than the level of employability (E-index) taken in a broader aspect. However, the relative conditions of the centres are very similar nationally; although the bottlenecks might be different, their employability relations are generally outstanding on the national level considering their opportunities.

Funding Information Open access funding provided by University of Pécs (PTE).

\section{Compliance with Ethical Standards}

Conflict of Interest The authors declare that they have no conflict of interest.

Open Access This article is distributed under the terms of the Creative Commons Attribution 4.0 International License (http://creativecommons.org/licenses/by/4.0/), which permits unrestricted use, distribution, and reproduction in any medium, provided you give appropriate credit to the original author(s) and the source, provide a link to the Creative Commons license, and indicate if changes were made.

\section{References}

Alpek, B. L., \& Tésits, R. (2017). A foglalkoztathatóság fogalmi kerete és dimenziói Magyarországon. Gazdaság és Társadalom, 9(2), 99-122.

Alpek, B. L., \& Tésits, R. (2018). Az esélyhátrányok halmozódásának területi jellegzetességei és hatása a foglalkoztathatóságra Magyarországon. Tér-Gazdaság-Ember, 6(2-3), 12-38.

Annoni, P. and Kozovska, K. (2010). EU regional competitiveness index 2010. Brussels: European Commission, Joint Research Centre.

Blades, R., Fauth, B., \& Gibb, J. (2012). Measuring employability skills: A rapid review to inform development of tools for project evaluation (Vol. 39). London: National Children's Bureau.

Cseres-Gergely, Z. (2014). A közfoglalkoztatásba belépök összetétele, 2011-2012. In: K. Fazekas, J. Varga (Ed.) (2014). Munkaerőpiaci tükör 2014. Budapest: MTA KRTK, Közgazdaság-tudományi Intézet, 118-126.

Dacre Pool, L., \& Sewell, P. (2007). The key to employability: Developing a practical model of graduate employability. Education+Training, 49(4), 277-289. https://doi.org/10.1108/00400910710754435.

Dusek, T. and Kotosz, B. (2016). Területi statisztika. Budapest: Akadémiai Kiadó, 286 p.

Forrier, A., \& Sels, L. (2003). The concept employability: A complex mosaic. International Journal of Human Resources Development and Management, 3(2), 102-124. https://doi.org/10.1504/ijhrdm.2003.002414.

Fugate, M., Kinicki, A. J., \& Ashforth, B. E. (2004). Employability: A psycho-social construct, its dimensions, and applications. Journal of Vocational Behavior, 65(1), 14-38. https://doi.org/10.1016/j. jvb.2003.10.005.

Getis, A., \& Ord, J. K. (1992). The analysis of spatial association by use of distance statistics. Geographical Analysis, 24(3), 189-206.

Harvey, L. (2001). Defining and measuring employability. Quality in Higher Education, 7(2), 97-109. https://doi.org/10.1080/13538320120059990.

Hillage, J., \& Pollard, E. (1998). Employability: Developing a framework for policy analysis. London: DfEE.

Huovari, J., Kangasharju, A., \& Alanen, A. (2002). Constructing an index for regional competitiveness. In Z. J. Acs, H. L. F. Groot, \& P. Nijkamp (Eds.), 2002: The emergence of the knowledge economy (pp. 121138). Berlin, Heidelberg: Springer.

Kitson, M., Martin, R., \& Tyler, P. (2004). Regional competitiveness: An elusive yet key concept? Regional Studies, 38(9), 991-999.

Kun, Z. (2008). A szociális szolgáltatások sztenderdizálása és a foglalkoztathatóság javítása. Kapocs, 7(5) 21 p. 
Lukovics, M. (2008). A térbeli különbségek alakulásának komplex vizsgálati módszere kistérségek példáján. In I. Lengyel \& M. Lukovics (Eds.), 2008: Kérdőjelek a régiók gazdasági fejlödésében (Vol. 309, pp. 248-263). Szeged: JATE Press.

McQuaid, R. W. (2006). Job search success and employability in local labor markets. The Annals of Regional Science, 40(2), 407-421. https://doi.org/10.1007/s00168-006-0065-7.

McQuaid, R. W., \& Lindsay, C. (2005). The concept of employability. Urban Studies, 42(2), 197-219. https://doi.org/10.1080/0042098042000316100.

Nemeskéri, Z. (2014). A foglalkoztathatóság általános kompetencia követelményei. Munkaügyi Szemle, 57(2), 65-71.

Peck, J., \& Theodore, N. (2000). Beyond 'employability'. Cambridge Journal of Economics, 24(6), 729-749. https://doi.org/10.1093/cje/24.6.729.

Pénzes, J. (2014). Periférikus térségek lehatárolása-dilemmák és lehetőségek. Didakt Kft., Debrecen, 140 p.

Sajtos, L. and Mitev, A. (2007). SPSS kutatási és adatelemzési kézikönyv. Aliena Kiadó 402 p.

Szakálné Kanó, I. (2011). A gazdasági aktivitás térbeli eloszlásának vizsgálati lehetőségei. Statisztikai Szemle, 89(1), 77-100.

Tésits, R., Alpek, B. L., \& Hoványi, G. (2018). A komplex, országos humánerőforrás-fejlesztés néhány tapasztalata a konvergenciarégiókban. Szociálpedagógia, 6(1-2), 86-103.

Thijsen, J. G. L. (2000). Employability in the brandpunt. Aanzet tot verhaldering van een diffuus fenomen. Tijdschrift HRM, 1, 7-34.

Thijssen, J. G., Van der Heijden, B. I. J. M., \& Rocco, T. S. (2008). Toward the employability-link model: Current employment transition to future employment perspectives. Human Resource Development Review, 7(2), 165-183. https://doi.org/10.1177/1534484308314955.

Vida, G. (2016). Az egyenlőtlen politikai reprezentációt létrehozó választási földrajzi hatótényezők mérési lehetöségei. Területi Statisztika, 56(6), 643-659. https://doi.org/10.15196/TS560603.

Vida, G., \& Dudás, G. (2017). Geographical context of the revealed competitiveness of urbanised areas in Hungary excluding the Budapest agglomeration. Geographica Pannonica, 21(3), 179-190. https://doi. org/10.5937/GeoPan1703179V.

Yorke, M. (2006). Employability in higher education: What it is-what it is not (Vol. 1). York: Higher Education Academy.

Yorke, M., \& Knight, P. T. (2006). Embedding employability into the curriculum (Vol. 3). Learning\&Employability, series one (p. 28). York: The Higher Education Academy.

\section{Other Sources}

Bologna Process. Stocktaking Report 2009. Report from the working groups appointed by the Bologna follow-up group to the ministerial conference in Leuven-Louvain-la-Neuve 28-29 April. 15 p.

Europe 2020 Strategy: A European strategy for smart, sustainable and inclusive growth. Communi-cation from the Commission, Brussels, 2010. 37 p.

European Commission Brussels, 2014: Draft joint employment Report from the commission and the council accompanying the communication from the commission on the annual growth survey 2015. $47 \mathrm{p}$.

KSH [Hungarian Central Statistical Office], 2016. http://ksh.hu/. Accessed 7 Oct 2018.

Publisher's Note Springer Nature remains neutral with regard to jurisdictional claims in published maps and institutional affiliations. 